\title{
A PROSPECTIVE STUDY OF CHANGES IN VARIOUS METABOLIC PARAMETERS IN PERIMENOPAUSAL WOMEN OF TWO DIFFERENT SOCIOECONOMIC STATUS
}

\author{
D. Shakeela ${ }^{1}$, P. Raja Babu² \\ ${ }^{1}$ Associate Professor, Department of Physiology, Rangaraya Medical College, Kakinada. \\ ${ }^{2}$ Associate Professor, Department of Physiology, ACSR, Govt. Medical College, Nellore.
}

\begin{abstract}
The World Health Organisation defines perimenopause as the period (2-8 yrs.) preceding menopause and the one year after final menses resulting from the loss of ovarian follicular activity.(1,2) It can be described as a woman goes from a state of normal cyclicity to an ultimate state of permanent hypergonadotropic hypogonadism and amenorrhoea. This study has been designed to study changes in various parameters in perimenopausal women belonging to two socioeconomic groups. All the parameter was measured before the start of the study and at the end of study. After two years it was found that there was changes in parameter in both the group, but changes in high socioeconomic.
\end{abstract}

\section{KEYWORDS}

Perimenopause, Metabolic Parameters, Socioeconomic Status.

HOW TO CITE THIS ARTICLE: D. Shakeela, P. Raja Babu. "A Prospective Study of Changes in Various Metabolic Parameters in Perimenopausal Women of two different Socioeconomic Status." Journal of Evolution of Medical and Dental Sciences 2015; Vol. 4, Issue 96, November 30; Page: 16141-16143, DOI: 10.14260/jemds/2015/2366

\section{INTRODUCTION}

The World Health Organisation defines perimenopause as the period (2-8 yrs.) preceding menopause and the one year after final menses resulting from the loss of ovarian follicular activity.(1,2) It can be described as a woman goes from a state of normal cyclicity to an ultimate state of permanent hypergonadotropic hypogonadism and amenorrhoea. The rate of increase in mortality and morbidity has been accelerated due to CHD after perimenopausal period. Lipid profile used to change with age in both the sexes, but in male this change used to start in third decade, but in woman it starts in 5th decade. $(3,4)$

In various study it has been found that ovarian hormone deficiencies or perimenopausal state is associated with reduced insulin sensitivity.(5) Considering these facts, this study has been designed to study changes in various parameters in perimenopausal women belonging to two socioeconomic groups.

\section{MATERIAL AND METHOD}

This is a prospective study carried out in coastal district of Andhra Pradesh, in the Dept. of Physiology, Rangaraya Medical College. Before start of the study permission from the institutional ethics committee was obtained. Written consent was taken from the patient enrolled for the study in two languages. Forty women between age group 45 to 55 yrs. were selected; out of 40 patients 20 were housewives from middle class family having annual income of the family more than 5 lakhs/annum; rest 20 patients were from family where income was less than 2 lakhs per annum and these woman were working 6 to $8 \mathrm{hrs}$ a day. They were selected as per exclusion criteria and enrolled for study.

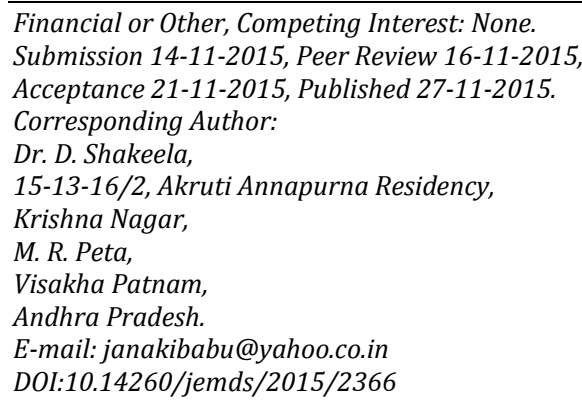

\section{Exclusion Criteria \\ - Diabetes mellitus \\ - Renal and hepatic dysfunction \\ - Hypertension \\ - Any kind of medication}

The study period was from Sept. 2013 to Oct. 2015. Various parameters like FBS, PPBS, lipid profile, fast and postprandial C-peptide assay were estimated. LDL-c was estimated by W.T. Friedowald, R.I. lery and D.C. Friedrickson method; serum triglyceride estimated by method of Neri and Fringe 1973 modified Debnath 1978. HDL estimated by precipitation method and serum cholesterol by ZAK modified method of 1957. C-peptide assay was done by radioimmunoassay.

Information about hot flashes, irritability, physical limitations, sexual dysfunction, sleep disorders and wt. gain were obtained every 3 months. Height, weight, body mass index were measured before start of the study and the end of the study. Data obtained before start of the study and at the end of the year were analysed.

\section{RESULT}

All the parameters were measured before the start of the study and at the end of study.

As per Table 1, the mean age of woman enrolled for study in group A was 49.9 and group B was 51.1 years. The body mass index in group A was 20.02 and group B was 25.02. Waist circumferences was $90 \mathrm{~cm}$ for group A and $82 \mathrm{~cm}$ for group B. Mean weight of women in group A was $70 \mathrm{~kg}$ and group B was $66 \mathrm{~kg}$. Mean fasting blood sugar at the start of study was $88 \mathrm{mg} / \mathrm{dl}$ and group B was $86 \mathrm{mg} / \mathrm{dl}$.

\begin{tabular}{|c|c|c|}
\hline & Gr A (mean) & Gr B (mean) \\
\hline Age (Year) & 49.9 & 51.1 \\
\hline BMI & 28.02 & 25.06 \\
\hline Waist (CM) & 90 & 82 \\
\hline Weight (KG) & 70 & 66 \\
\hline FBs (mg/dl) & 88 & 80 \\
\hline \multicolumn{3}{|c|}{ Table 1 } \\
\hline
\end{tabular}

After two years of premenopausal age, the percentage change in mean LDL concentration in group A was $5 \%$ with $t$ - 
value 2.51 and $p$ value $<0.05$. Change in the outcome of $L D L$ for group $B$ was $6 \%$ with ' $t$ ' value 2.33 and $p$ value $<0.05$.

The percentage change in the mean triglyceride concentration was $12.4 \%$ in group $\mathrm{A}$ and it was $5.0 \%$ in group B. Mean concentration of serum cholesterol in group A was increased by $3 \%$ with ' $t$ ' value 1.90 and $P$ value $>0.05$.
Similarly, in group B it was $3.7 \%$ with ' $t$ ' value 2.83 and $P$ value $<0.05$.

In group A the mean HDL concentration was decreased by $11.36 \%$ and group $B$ it was $2.2 \%$; reduction in the concentration of HDL in group B was not significant.

\begin{tabular}{|c|c|c|c|c|}
\hline & & Mean & T value & P value \\
\hline \multirow{4}{*}{ LDL } & \multirow{2}{*}{ Gr A } & start - 143.2 & \multirow{2}{*}{2.51} & \multirow{2}{*}{$<0.05$} \\
\hline & & After 2Yrs 150.8 & & \\
\hline & \multirow{2}{*}{ Gr B } & start - 135.6 & \multirow{2}{*}{2.31} & \multirow{2}{*}{$<0.05$} \\
\hline & & After 2Yrs 144.6 & & \\
\hline \multirow{4}{*}{ HDL } & \multirow{2}{*}{ Gr A } & start - 44.6 & \multirow{2}{*}{2.9} & \multirow{2}{*}{$<0.05$} \\
\hline & & After 2Yrs 39.6 & & \\
\hline & \multirow{2}{*}{ Gr B } & start - 45.2 & \multirow{2}{*}{1.6} & \multirow{2}{*}{$<0.05$} \\
\hline & & After 2Yrs 44.2 & & \\
\hline \multirow{4}{*}{ TG } & \multirow{2}{*}{ Gr A } & start - 174.2 & \multirow{2}{*}{8.79} & \multirow{2}{*}{$<0.05$} \\
\hline & & After 2Yrs 195.8 & & \\
\hline & \multirow{2}{*}{ Gr B } & start - 166.6 & \multirow{2}{*}{4.75} & \multirow{2}{*}{$<0.05$} \\
\hline & & After 2Yrs 175.6 & & \\
\hline \multirow{4}{*}{ Chol } & \multirow{2}{*}{ Gr A } & start - 177.2 & \multirow{2}{*}{1.9} & \multirow{2}{*}{$<0.05$} \\
\hline & & After 2Yrs 182.2 & & \\
\hline & \multirow{2}{*}{ Gr B } & start - 149.5 & \multirow{2}{*}{2.83} & \multirow{2}{*}{$<0.05$} \\
\hline & & After 2Yrs 156.0 & & \\
\hline & b ? & $\begin{array}{l}\text { Profile at Start a } \\
\text { y in Perimenopa }\end{array}$ & $\begin{array}{l}\text { Two } Y \\
\text { en }\end{array}$ & \\
\hline
\end{tabular}

Fasting mean C-peptide concentration in group A was also increased by $32 \%$ and in group B it was $40 \%$, so there was significant increase in the $\mathrm{C}$-peptide concentration.

\begin{tabular}{|c|c|c|c|c|}
\hline & & Mean & T value & P value \\
\hline \multirow{2}{*}{ Gr A } & Start & 0.828 & \multirow{2}{*}{5.45} & $<0.05$ \\
\cline { 2 - 4 } & After 2Yrs & 1.155 & & $<0.05$ \\
\hline \multirow{2}{*}{ Gr B } & Start & 0.462 & \multirow{2}{*}{4.83} & $<$ \\
\cline { 2 - 3 } & After 2Yrs & 0.944 & & $<$ \\
\hline \multicolumn{7}{|c|}{ Table 3: C-Peptide Concentration to Start and After 2hrs. of Study } \\
\hline
\end{tabular}

Now regarding symptoms of menopause, in both the groups various symptoms frequency has been increased out of all the parameters the weight gain and vaginal dryness was more frequent in both the groups after 2 years.

\begin{tabular}{|c|c|c|c|c|}
\hline & \multicolumn{2}{|c|}{ GROUP A } & \multicolumn{2}{c|}{ GROUP B } \\
\hline & BEFORE & AFTER & BEFORE & AFTER \\
\hline \multirow{2}{*}{ SYMPTOMS } & NO. OF & NO. OF & NO. OF & NO. OF \\
& FEMALES & FEMALES & FEMALES & FEMALES \\
\hline HOT FLUSHES & 10 & 14 & 8 & 10 \\
\hline IRRITABILITY & 6 & 10 & 4 & 6 \\
\hline PHYSICAL LIMITATION & 4 & 6 & 8 & 10 \\
\hline DEPRESSION & 8 & 10 & 6 & 10 \\
\hline FREQUENT MENSES & 10 & 18 & 10 & 18 \\
\hline VAGINAL DRYNESS & 8 & 14 & 6 & 12 \\
\hline SEXUAL DYSFUNCTION & 2 & 6 & 3 & 8 \\
\hline SLEEP DISORDER & 1 & 4 & 1 & 2 \\
\hline WEIGHT GAIN & 4 & 10 & 4 & 8 \\
\hline \multicolumn{2}{|l|}{ Table 4: SYMPTOMS BEFORE AND AFTER THE END OF THE STUDY } \\
\hline
\end{tabular}

\section{DISCUSSION}

Perimenopausal is a period of menstrual irregularity and hormonal variability. Cardiovascular disease risk factor used to increase.

\section{Changes in LDL in perimenopausal period}

There was significant increase in LDL concentration after two years of followup. The percentage change in mean LDL concentration in both the groups were increased, change in the group B was slightly more than group A. Various studies also found same result that changes in the LDL conc. used to occur in early transition peak of premenopausal period.$(7,8)$

\section{Changes in the HDL during perimenopausal period}

Some studies found that there is significant fall in HDL during perimenopausal period, but others found that there is no significant change. ${ }^{(9,10)}$ Kennel et al., but in our study there was significant fall in HDL in group with good socioeconomic 
status, but fall in HDL was not significant in poor socioeconomic status women with $11.30 \%$ and $2.2 \%$ respectively.

Change in the triglycerides concentration during perimenopausal period:

The percentage increase in mean TG concentration was more in Group A than Group B that was 12.4\% and 5\% respectively, which was significant statistically. Poehlman et al., found that TG concentration was increased by $16 \%$. .(11) $^{-1}$

Changes in serum cholesterol concentration during perimenopause:

Changes in the serum concentration of cholesterol was less; it has increased by $3 \%$ and $3.7 \%$ respectively in Group A and Group B, which was as per the study of authors.

\section{Changes in C-peptide concentration}

It has been found in various study that perimenopausal stage is a stage of change in sensitivity of insulin or transition into insulin resistance, so by various authors it has been found that C-peptide insulin level used to increase.(12,13) In our study also, we have found that there was significant increase in the Cpeptide concentration after $2 \mathrm{yrs}$. in perimenopausal period. Now regarding various clinical presentation of menopause, it has been found that frequent menses, hot flushes and vaginal dryness were common in both the group of women.

One of the important parts of our study is the difference in changes as per socioeconomic group. It has been found that changes in the parameter was less in low socioeconomic woman than in the good socioeconomic age group. Clinical presentation was same as the woman of working class, but as having calories consumption less and utilization was more, so that may be one of the causes of that. It is similar to the study of other worker.(14) But in Indian scenario, the studies are less and it has to be evaluated in detail.(15)

\section{CONCLUSION}

Aging process is one of the bitter truths of nature. The living thing who has taken birth has to grow old and die at some time. New born will replace them. But as we know that living condition and medical facilities has improved, so life expectancy has increased and we have more geriatric population. So graceful aging is the new concept and demand of these changing scenarios. That is why the better understanding of change in physiology is required. After two years it was found that there was changes in parameter in both the groups, but changes in high socioeconomic group was more. A thorough study of these changes is required by using more number of women and including more parameters and resources.

\section{BIBLIOGRAPHY}

1. World Health Organization. Research on the menopause in the 1990s: Report of a WHO scientific group. Geneva: WHO Technical Report Series number 866;1996.

2. Teede H, Burger HG. The menopausal transition. In: Studd JWW, editor. The Management of Menopause Annual Book Review. London, England: Parthenon Publishing Group; 1998:1-12.
3. Uring R, Matheus KA, Koller LH, Meilamn EN and Planting PL (1991) wt. gain at the time of menopause. Arch. Intern med 151:97-102.

4. US Department of Health and Human Services Public Health Service National Inst. of Health (1980). The lipid research clinics population studies data book. Vol. The preference study NIH publ. no. 80-152> USDHHS PHS NIH Bethesda MD.

5. Rincon J, Holmang A, Wahlstrom EO, Lon-nroth $\mathrm{P}$, Bjorntorp P, Zierath JR, Wallberg-Henriksson $\mathrm{H}$ : Mechanisms behind insulin resistance in rat skeletal muscle after oophorectomy and additional testosterone treatment. Diabetes45:615-621, 199.

6. Gohlke-Barwolf C 2000 Coronary artery disease: Is menopause a risk factor? Basic Res Cardiol 95 (Suppl 1):I77-I83.

7. Campos H, McNamara JR, Wilson PW, Ordovas JM, Schaefer EJ. 1988 Differences in low density lipoprotein subfractions and apolipoproteins in premenopausal and postmenopausal women. J Clin Endocrinol Metab 67:3035.

8. Li Z, McNamara JR, Fruchart JC, Luc G, Bard JM, Ordovas JM, Wilson PW, Schaefer EJ. 1996.Effects of gender and menopausal status on plasma lipoprotein subspecies and particle sizes. J Lipid Res 37:1886-1896.

9. Longitudinal study of risk factors for coronary heart disease across the menopausal transition. Am J Epidemiol 151:584-593.

10. Kannel WB, Hjortland MC, McNamara PM, Gordon T. 1976 Menopause and risk of cardiovascular disease: The Framingham study. Ann Intern Med 85:447-452.

11. Poehlman ET, Toth MJ, Ades PA, Rosen CJ. 1997 Menopause-associated changes in plasma lipids, insulinlike growth factor I and blood pressure: A longitudinal study. Eur J Clin Invest 27:322-326.

12. Lazarus R, Sparrow D, Weiss S. Temporal relations between obesity and insulin: Longitudinal data from the normative aging study. Am J Epidemiol 1998;147:173179.

13. Hodge AM, Dowse GK, Alberti KG, Gareeboo H, Tuomilehto J, Zimmet PZ. Relationship of insulin resistance to weight gain in non-diabetic Asian Indian, Creol, and Chinese Mauritians. Metabolism 1996;45:627-633.

14. J Epidemiol Community Health 2002;56:851-860 doi:10.1136/jech.56.11.851 Research report Lifetime socioeconomic position in relation to onset of perimenopause L A Wise1,4, N Krieger2, S Zierler3, B L Harlow1.

15. *Mrs. Amruthavall BN, **Prof. VenkataRamana G. Impact of socio-economic factors on health problems of menopausal Muslim women, a study in Anantapuramu District, Andhra Pradesh. Journal Of Humanities and Social Science (IOSRJHSS) Volume 20, Issue 9, Ver. V (Sep. 2015). 